\title{
Nicotinic Receptor Activation Excites Distinct Subtypes of Interneurons in the Rat Hippocampus
}

\author{
A. Rory McQuiston and Daniel V. Madison \\ Department of Molecular and Cellular Physiology, Stanford University School of Medicine, Stanford, California 94305
}

\begin{abstract}
We examined the function of nicotinic acetylcholine receptors (nAChRs) in interneurons of area CA1 of the rat hippocampus. CA1 interneurons could be classified into three categories based on nicotinic responses. The first class was depolarized by $\alpha 7$ nAChRs, found in all layers of CA1 and as a group, had axonal projections to all neuropil layers of CA1. The second class had both fast $\alpha 7$ and slow non- $\alpha 7$ nAChR depolarizing responses, was localized primarily to the stratum oriens, and had axonal projections to the stratum lacunosum-moleculare. The third group had no nicotinic response. This group was
\end{abstract}

found in or near the stratum pyramidale and had axonal projections almost exclusively within and around this layer. Low concentrations (500 nM) of nicotine desensitized fast and slow $\mathrm{nAChR}$ responses. These findings demonstrate that there are distinct subsets of interneurons with regard to nicotinic receptor expression and with predictable morphological properties that suggest potential cellular actions for nicotinic receptor activation in normal CNS function and during nicotine abuse.

Key words: hippocampus; CA1; interneuron; subtypes; nicotinic receptor; $\alpha 7$; non- $\alpha 7$; nicotine
One important target for the actions of nicotine in the hippocampus appears to be the inhibitory interneurons. Anatomically, interneurons of the hippocampus express at least the $\alpha 7$ subtype of nicotinic receptors, as shown by $\alpha$-bungarotoxin $(\alpha$-BgTx) binding (Freedman et al., 1993). These receptors are found underlying synapses on interneuronal somata (Hunt and Schmidt, 1978). Furthermore, cholinergic boutons have been found adjacent to somata of CA1 interneurons (Frotscher et al., 1989), and in situ hybridization studies have shown that the hippocampus expresses $\alpha 2-4, \alpha 7$, and $\beta 2$ nicotinic acetylcholine receptor (nAChR) mRNA subunits (Wada et al., 1989; Séguéla et al., 1993). $\alpha 7$ nicotinic receptor activity has also been shown to directly excite morphologically unidentified interneurons (Alkondon and Albuquerque, 1991; Reece and Schwartzkroin, 1991; Albuquerque et al., 1995; Alkondon et al., 1997; Jones and Yakel, 1997; Frazier et al., 1998a), and cultured hippocampal neurons appear to express three different nAChR subtypes (Alkondon and Albuquerque, 1993). Pyramidal cells, on the other hand, may not have nicotinic receptors (Frazier et al., 1998a, but see Alkondon et al., 1997).

Although they comprise perhaps only $10-15 \%$ of the neurons in hippocampus, interneurons are extremely influential in the control of hippocampal circuitry because their divergent connections modulate virtually all activity of the more numerous principal neurons. Interneurons comprise a very diverse group, with a wide variety of specialized dendritic and axonal arbors. Different

\footnotetext{
Received Nov. 19, 1998; revised Jan. 26, 1999; accepted Jan. 28, 1999.

This work was supported by National Institute of Mental Health Grants MH48874 and MH56454 to D.V.M. We would like to thank Eric Schaible and Paul Pavlidis for writing the acquisition and analysis software, Isabel Parada-Riquelme for advice on histological procedures, David Prince and John Huguenard for allowing us to use of their Neurolucida for neuronal reconstructions, and Bill Colmers, Van Doze, Brie Linkenhoker, and Bruce MacIver for helpful discussions and careful reading of this manuscript. We are grateful to B. Olivera for the gifts of $\alpha$-conotoxin ImI and $\alpha$-conotoxin MII.

Correspondence should be addressed to Daniel V. Madison, Department of Molecular and Cellular Physiology, Beckman Center, Room 111, Stanford University School of Medicine, Stanford, CA 94305-5345.

Copyright (C) 1999 Society for Neuroscience $\quad 0270-6474 / 99 / 192887-10 \$ 05.00 / 0$
}

types of interneurons would appear to perform specific and varying functions in the hippocampus (for review, see Freund and Buzsaki, 1996). For example, some interneurons potently inhibit pyramidal cells by acting directly on their cell bodies or axon hillocks (Gulyas et al., 1993a; Buhl et al., 1994; McBain et al., 1994; Sik et al., 1995; Miles et al., 1996), whereas others inhibit pyramidal cell activity at their dendrites (Han et al., 1993; Gulyas et al., 1993a,b; Sik et al., 1995; Miles et al., 1996). Another group of interneurons appears to specifically inhibit other interneurons (Acsady et al., 1996a,b; Gulyas and Freund, 1996; Hajos et al., 1996). Information on how nicotine affects these different types of interneurons will be valuable in assessing and understanding the role of acetylcholine (ACh) in influencing hippocampal and brain circuitry.

In this study we have explored the actions of nAChR activity on subtypes of hippocampal interneurons and pyramidal cells. By recording the membrane currents and potentials that result from rapid application of $\mathrm{ACh}$ in whole-cell mode and comparing those responses to the morphology of reconstructed interneurons, we have determined that the distribution of $\mathrm{nAChRs}$ varies with interneuronal morphology. Specifically, the type of nicotinic response that an interneuron has is strongly correlated with the target of its axonal arbors. In our study, we have found pyramidal cells rarely show nicotinic responses, and when present these responses are much smaller than in interneurons. In all cases, low doses of nicotine are sufficient to significantly reduce responses to rapidly applied $\mathrm{ACh}$, presumably by desensitizing nicotinic receptors. These nicotinic actions in conjunction with the correlated anatomical characteristics suggest specific roles for the nicotinic synapses on interneurons in CA1.

\section{MATERIALS AND METHODS}

Young rats (16- to 54-d-old) were killed under halothane anesthesia by decapitation, and their brains were rapidly removed and placed in cold $\left(4^{\circ} \mathrm{C}\right.$ ) saline (in mu: $\mathrm{NaCl} 119, \mathrm{KCl} 2.5, \mathrm{CaCl}_{2} 1.0, \mathrm{MgCl}_{2} 3, \mathrm{NaHPO}_{4} 1$, $\mathrm{NaHCO}_{3} 26.2$, glucose 11 , and kynurenic acid 1) bubbled with $95 \% \mathrm{O}_{2}$ and $5 \% \mathrm{CO}_{2}, \mathrm{pH}$ 7.4. The brain was then hemisected, and singlehemisphere coronal slices (300- to $400-\mu \mathrm{m}$-thick) were cut on a Vi- 
bratome (Lancer) and placed submerged in an incubation chamber at $30^{\circ} \mathrm{C}$ for $30 \mathrm{~min}$. The slices were then allowed to cool down to room temperature $\left(\sim 23^{\circ} \mathrm{C}\right)$ and recorded from over the next $2-4 \mathrm{hr}$.

Whole-cell patch-clamp recordings were made from visualized interneurons in all layers of area CA1 in the hippocampus (MacVicar, 1984; Dodt and Zieglgansberger, 1990). Slices were constantly superfused with room temperature saline (in mM: $\mathrm{NaCl} 119, \mathrm{KCl} 2.5, \mathrm{CaCl}_{2} 2.5, \mathrm{MgSO}_{4}$ 1.3, $\mathrm{NaHPO}_{4} 1, \mathrm{NaHCO}_{3}$ 26.2, glucose 11, atropine sulfate 1-5, pH 7.4, bubbled with $95 \% \mathrm{O}_{2}$ and $\left.5 \% \mathrm{CO}_{2}\right)\left(22-24^{\circ} \mathrm{C}\right)$ in a recording chamber mounted on the stage of a modified Nikon Optiphot 2 microscope. Near infrared light illuminated the brain slice placed on a cover glass bottom of the recording chamber and collected by a $40 \times$ water immersion objective, magnified an additional $1.2 \times$ before the image was collected by an intensified CCD camera (Hamamatsu) with contrast enhancement. The image of the cells in the slice was displayed on a video monitor, and glass patch pipettes were visually advanced through the slice to the surface of the cell from which we recorded.

Patch pipettes were fabricated from borosilicate glass (KG33; $1.5 \mathrm{~mm}$ outer diameter, $1.0 \mathrm{~mm}$ inner diameter; Garner Glass Company) and filled with one of two intracellular solutions, either (in $\mathrm{mM}$ :) $\mathrm{KCH}_{3} \mathrm{SO}_{4}$ 130, $\mathrm{NaCl}$ 8, HEPES 10, MgATP 2, $\mathrm{Na}_{3}$ GTP 0.3, and BAPTAK 4 0.1, pH 7.25 or a similar solution substituting $\mathrm{Cs}$ gluconate for $\mathrm{KCH}_{3} \mathrm{SO}_{4}$. When neurobiotin $(0.5 \%)$ was included in the internal solution to label cells, $\mathrm{KCH}_{3} \mathrm{SO}_{4}$ was reduced to $120 \mathrm{~mm}$ to maintain similar osmolarity.

Membrane potentials and currents from interneurons were monitored with an Axoclamp 2A amplifier (Axon Instruments, Foster City, CA), acquired through a MIO-16-E2 A/D interface (National Instruments) onto a Pentium personal computer using software written in Labview by members of the lab (Eric Schaible and Paul Pavlidis). Data were analyzed using another program written in Labview and in Axum (Mathsoft Inc.), a commercially available program. Statistical significance was determined by a z-score or a two-tailed unpaired Student's $t$ test, as indicated. Mean values are reported as mean \pm SEM. Membrane potentials were corrected for junction potentials by $12 \mathrm{mV}$, as empirically determined by Neher (1992).

Nicotinic currents were evoked by ejecting ACh through a small tipped $(<1 \mu \mathrm{m})$ pipette that was moved under visual control to within $\sim 30 \mu \mathrm{m}$ of the soma of the neuron under study. The solution was pressure-ejected (100 msec, $10 \mathrm{psi}$ ) directly onto the cell body and proximal dendrites using a Picospritzer II (General Valve, Fairfield, NJ). The pipette solution contained $3 \mathrm{~mm}$ ACh dissolved in extracellular saline, $\mathrm{pH} 7.4$, as described above, except that HEPES was substituted for $\mathrm{NaHCO}_{3}$. Other drugs and chemicals were applied by bath perfusion.

Standard histological processing for biotin was performed to visualize the interneurons filled with neurobiotin (Bolam, 1992). Briefly, slices were fixed overnight in a $0.1 \mathrm{M}$ phosphate buffer solution containing $4 \%$ paraformaldehyde, $0.05 \%$ glutaraldehyde, and $0.2 \%$ picric acid. Slices were then embedded in gelatin and resectioned to $100 \mu \mathrm{m}$. Sections were permeabilized with $0.5 \%$ Triton $\mathrm{X}-100$, treated with $0.3 \%$ hydrogen peroxide to reduce background peroxidase activity, and incubated overnight in avidin-biotin-peroxidase complex. The next day, the sections were stained with diaminobenzidine, intensified with nickel, mounted on slides, cleared, and then coverslipped. Neurons were reconstructed using a Neurolucida.

All chemicals were purchased from Fluka except for the following: $\alpha$-bungarotoxin, mecamylamine (MEC), dihydro- $\beta$-erythroidine ( $\mathrm{DH} \beta \mathrm{E})$, methyllycaconitine (MLA), 6-nitro-7-sulfamoylbenzo[f]quinoxaline-2,3dione (NBQX), D(-)-2-amino-5-phosphonopentanoic acid (D-APV), bicuculline methiodide (BIC; Research Biochemicals, Natick, MA), tetrodotoxin (TTX; Calbiochem, La Jolla, CA), $\mathrm{KCH}_{3} \mathrm{SO}_{4}$ (ICN Biochemicals, Costa Mesa, CA), and paraformaldehyde (Electron Microscope Sciences). $\alpha$-Conotoxin ImI ( $\alpha$-CTX ImI) and $\alpha$-conotoxin MII ( $\alpha$-CTX MII) were generous gifts from Dr. B. Olivera (University of Utah, Salt Lake City, UT).

\section{RESULTS}

We used the whole-cell patch-clamp technique on area CA1 interneurons visualized in hippocampal slices with Nomarski optics under infrared illumination (IR-DIC). This study includes the data from recordings of 159 interneurons and 15 pyramidal cells in all layers of area CA1. ACh $(3 \mathrm{~mm})$ was applied in brief pulses directly to neurons by pressure ejection from a nearby patch electrode. All responses were recorded in the presence of 1-5 $\mu \mathrm{M}$ atropine to prevent muscarinic responses.

\section{Interneurons with fast $\alpha \mathbf{7}$ AChR-mediated responses}

The most common nicotinic response observed is illustrated in Figure 1. Application of a brief $(100 \mathrm{msec})$ puff of $3 \mathrm{~mm}$ ACh caused a rapid depolarization of the membrane potential and a burst of action potentials (Fig. $1 A_{1}$, right). When the membrane potential was voltage-clamped near resting membrane potential $\left(V_{\mathrm{H}}=-70 \mathrm{mV}\right), 3 \mathrm{~mm} \mathrm{ACh}$ produced a rapidly activating and deinactivating inward current (mean amplitude, $680 \pm 705 \mathrm{pA}$; $n=99$ ) (Fig. $1 A_{2,3}$ ). Application of the $\alpha 7$ nAChR-selective partial antagonist $\alpha$-CTX ImI (McIntosh et al., 1994; Johnson et al., 1995; Pereira et al., 1996) inhibited the nicotinic inward current in a reversible manner (Fig. $1 A_{2}, B ; 55.3 \pm 7.3 \%$ of control; $n=3 ; p=0.00015$, z-score). Low concentrations of the selective $\alpha 7$ antagonists MLA (1-10 nM) (Fig. $1 A_{3}, B ; 0.1 \pm 0.1 \%$ of control; $n=16 ; p=0.000015, \mathrm{z}$-score) and $\alpha$-BgTx (100 nм) (Fig. $1 B ; 0 \pm 0 \%$ of control; $n=9 ; p=0.000015$, z-score) both completely inhibited this fast nicotinic current in a reversible and irreversible manner, respectively. However, the less selective inhibitor MEC $(1 \mu \mathrm{M})$ had only a small but significant effect (Fig. $1 B ; 90.2 \pm 3.3 \%$ of control; $n=5 ; p=0.037$, z-score), whereas $\mathrm{DH} \beta \mathrm{E}$ (Fig. $1 B ; 100 \mathrm{~nm} ; 100.6 \pm 3.2 \% ; n=4 ; p=0.26$, z-score) had no effect. These pharmacological observations suggest that this fast nicotinic response is mediated by $\alpha 7 \mathrm{nAChRs}$.

Previous studies have shown that nAChRs can cause the release of neurotransmitters in the hippocampus (Alkondon et al., 1997; Wonnacott, 1997) through the activation of nAChRs on the presynaptic terminals (Gray et al., 1996; Wonnacott, 1997). We sought to determine whether the nicotinic responses we observed were caused by the direct activation of postsynaptic nAChRs or indirectly through the release of neurotransmitter onto the interneuron via the activation of nAChRs on the presynaptic terminals. Inhibiting ionotropic glutamate receptors (NBQX, $30 \mu \mathrm{M}$; D-APV, $50 \mu \mathrm{M})\left(\right.$ Fig. $1 B$ ) and $\mathrm{GABA}_{\mathrm{A}}$ receptors (bicuculline, 10 $\mu \mathrm{M}$ ) (Fig. $1 B ; 99.7 \pm 2.7 \%$ of control; $p=0.24 ; n=4$ ) did not inhibit nicotine responses nor did inhibiting voltage-dependent calcium channels (VDCC) with cadmium $\left(\mathrm{Cd}^{2+} ; 200 \mu \mathrm{M}\right)($ Fig. $1 B)$ and voltage-dependent sodium $\left(\mathrm{Na}^{2+}\right)$ channels (VDSC) with TTX $(1 \mu \mathrm{M})($ Fig. $1 B ; 98.0 \pm 1.2 \%$ of control; $p=0.075 ; n=$ 4). Therefore, the nicotinic responses are likely caused by direct activation of postsynaptic nAChRs consistent with receptor localization studies in slices (Hunt and Schmidt, 1978; Freedman et al., 1993).

Neuronal nAChRs have previously been shown to have inwardly rectifying current-voltage $(I-V)$ relationships, passing little outward current and having zero current between 0 and 10 $\mathrm{mV}$ (for review, see Role, 1992). To examine the $I-V$ relationship of these fast nicotinic currents, we recorded the nicotinic currents with an intracellular solution containing $\mathrm{Cs}^{+}$instead of $\mathrm{K}^{+}$to block $\mathrm{K}^{+}$currents, extracellular TTX $(1 \mu \mathrm{M})$ to block VDSCs, and $\mathrm{Cd}^{2+}(200 \mu \mathrm{M})$ to block VDCCs. This allowed for better control of the membrane potential at more depolarized potentials and prevented action potentials and calcium-dependent neurotransmitter release. Consistent with previous findings, fast nicotinic responses, when measured at varying membrane potentials, produced an inwardly rectifying $I-V$ relationship, passing reduced (Fig. 1C) outward current at positive membrane potentials. As expected for the magnesium concentration in our internal solution, this rectification was not complete (cf. Albuquerque et al., 1996), but on average, near zero current was seen between mem- 

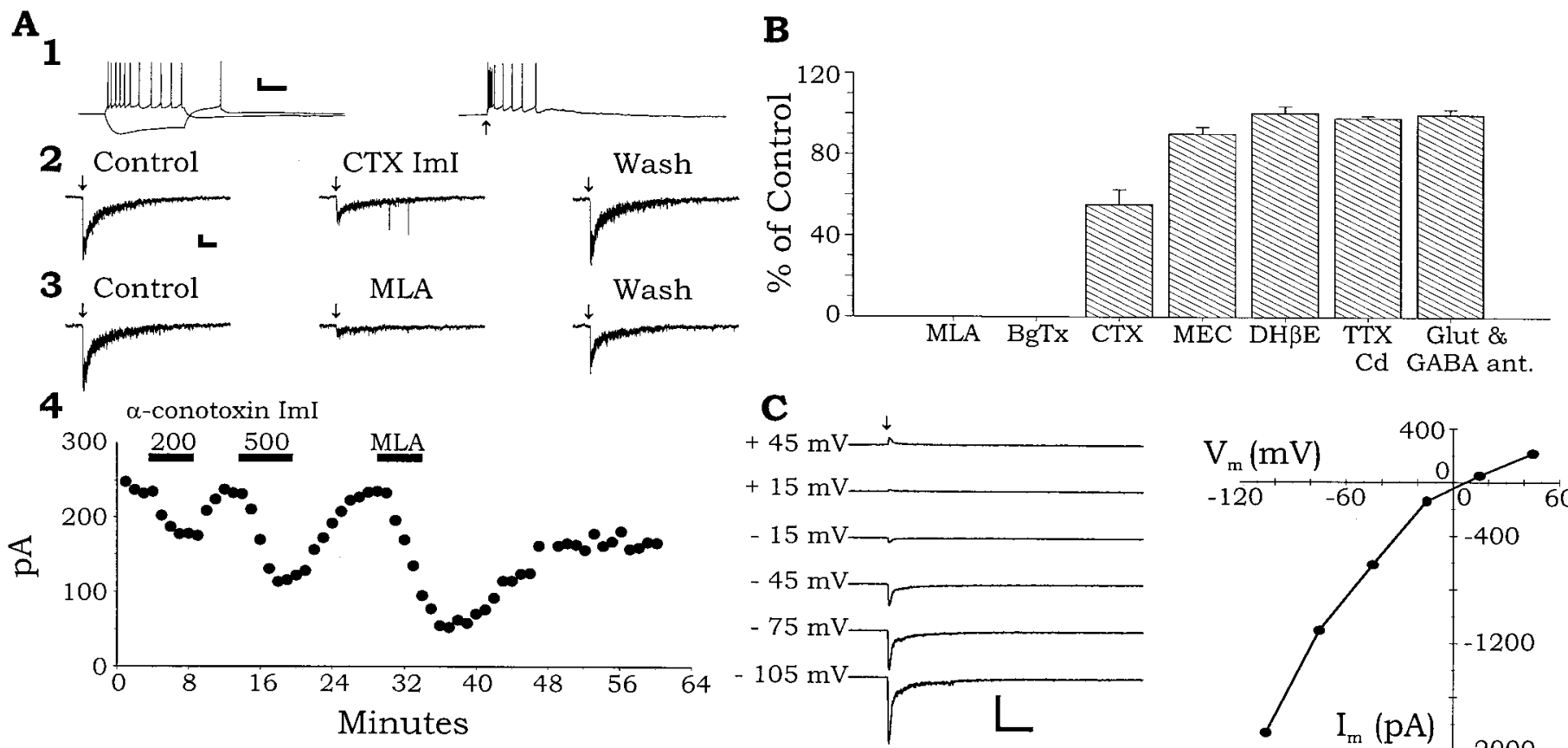

Figure 1. $\alpha 7$ NAChR activation excites most interneurons. $A$, Whole-cell recordings made from an interneuron located in SR at the border of SLM. $A_{1}$, Left, Electrophysiological responses to hyperpolarizing and depolarizing current injection (120 pA). Right, Application of 3 mM ACh by pressure application (100 msec, $10 \mathrm{psi}$ at the arrow, in the presence of $5 \mu \mathrm{M}$ atropine) caused a depolarization and evoked action potentials. $A_{2,3}$, In the same cell, under voltage clamp, the same pulse of ACh (arrow) produced a fast inward current that was reversibly inhibited in a dose-dependent manner by the $\alpha 7$ nicotinic antagonists $\alpha$-CTX ImI $\left(A_{2}, 500 \mathrm{nM}\right)$ and MLA $\left(A_{3}, 2 \mathrm{nM}\right) . A_{4}$, A plot of the peak currents versus time for the experiments in panels $A_{2}$ and $A_{3}$. B , Summary plot from a number of interneurons showing the effect of various antagonists on the peak inward currents induced by ACh ( 3 mu). $C$, In another interneuron, a current-voltage relationship was constructed for the ACh response. This current showed mild inward rectification and reversed between 0 and $+10 \mathrm{mV}$. Raw data traces are shown on the left with the holding potential for each current trace shown. ACh was applied as before, at the arrow. The peak currents are plotted against the membrane holding potential on the right. Calibration: $A_{1}$, Vertical, $20 \mathrm{mV}$, horizontal, left, $200 \mathrm{msec}$, right, $500 \mathrm{msec} ; A_{2,3}$, vertical, $40 \mathrm{pA}$, horizontal, $500 \mathrm{msec} ; B$, vertical, $100 \mathrm{pA}$, horizontal, $1 \mathrm{sec} ; C$, vertical, $1000 \mathrm{pA}$, horizontal, $500 \mathrm{msec}$. All arrows in all traces indicate the point at which $3 \mathrm{~mm}$ ACh was pressure-applied (100 $\mathrm{msec}, 10 \mathrm{psi})$ to the soma of the respective interneuron.

brane potentials of $0-10 \mathrm{mV}(+5.6 \pm 4.4 \mathrm{pA} ; n=14)$. Thus, the $I-V$ relationship of the fast nicotinic response is consistent with the activation of neuronal nAChRs.

\section{A subset of interneurons express two types of NAChRs}

A subset of interneurons in the stratum oriens (SO) showing horizontally oriented spindle-shaped cell bodies, when viewed in live slices with IR-DIC, responded to puffs of $3 \mathrm{mM} \mathrm{ACh}$ with the fast response and an additional slower response (Fig. $2 A_{2}$ ). The slow component was always seen in combination with a fast component. The fast response was identical to that seen in other interneurons. As in interneurons showing only the fast response, the fast phase of the nicotinic response was completely blocked by application of $\alpha$-BgTx (Fig. $2 A_{2} ; 100 \mathrm{~nm}$ ) or MLA (1-10 nM), but the slow response was unaffected. Recordings in current clamp (Fig. 2A , right) showed that the isolated slow response could cause the interneuron to fire a barrage of action potentials in response to a brief puff of $3 \mathrm{~mm} \mathrm{ACh}$. The presence of an $\alpha$-BgTx-insensitive slow response suggests that these neurons express an additional nAChR that is not of the $\alpha 7$ type. Depolarizing current injection into one of these interneurons produced a nonaccommodating train of action potentials (Fig. $2 A_{1}$ ), however, the presence or absence of accommodating trains of action potentials was not indicative of the presence or absence of a nicotinic slow component in an interneuron. In the illustrated neuron, a hyperpolarizing current injection resulted in a hyper- polarization with a depolarizing sag and after the termination of the pulse an overshoot of the resting membrane potential (Fig. $\left.2 A_{1}\right)$. Again, the presence of a depolarizing sag was not indicative of a cell displaying a slow nicotinic response.

In voltage clamp, the fast current was completely inhibited by the $\alpha 7 \mathrm{nAChR}$ antagonists $\alpha$-BgTx (100 nM; Fig. $\left.2 A_{2}\right)$ or $10 \mathrm{~nm}$ MLA (data not shown), but the slow component remained. To investigate the properties of this slower current in isolation, we performed all subsequent experiments in either $\alpha$-BgTx (100 nM) or MLA $(10 \mathrm{~nm})$ to inhibit the fast current. The nicotinic slow current (mean amplitude, $97.2 \pm 65.4 \mathrm{pA} ; n=52 ; V_{\mathrm{H}}=-70 \mathrm{mV}$ ) was not inhibited by the $\alpha 3 \beta 2$ nicotinic-selective antagonist $\alpha$-CTX MII (200 nм; $95.3 \pm 3.4 \%$ of control; $p=0.35$; z-score, $n=3$ ) (Fig. $2 A_{3}, B$ ) (Cartier et al., 1996). However, the slow current was reversibly inhibited by the nonselective nicotinic antagonist MEC $(1 \mu \mathrm{M})$ (Fig. $2 A_{4}, B ; 25.8 \pm 4.5 \%$ of control; $p=$ 0.00001 ; z-score, $n=6)$ and dose dependently by $\mathrm{DH} \beta \mathrm{E}(100 \mathrm{nM})$ (Fig. $2 A_{5}, B ; 74.6 \pm 7.5 \%$ of control; $p=0.032 ; n=10 ; 1 \mu \mathrm{M}$; $42.7 \pm 5.7 \%$ of control; $p=0.005$; z-score, $n=20$ ). These data suggest that in addition to expressing $\alpha 7$ receptors, this subset of interneurons also expresses another unidentified kinetically slower nAChR. As was the case with the fast response, glutamate antagonists (NBQX, $30 \mu \mathrm{M}$; D-APV, $50 \mu \mathrm{M}$ ) and $\mathrm{GABA}_{\mathrm{A}}$ antagonists (BIC; $10 \mu \mathrm{M}$; Fig. $2 B ; 96.4 \pm 2.7 \%$ of control; $p=0.3$; z-score, $n=6)$ and/or TTX $(1 \mu \mathrm{M})$ and $\mathrm{Cd}^{2+}(200 \mu \mathrm{M})(96.4 \pm$ $2.7 \%$ of control; $p=0.36$; z-score, $n=6$ ) did not inhibit the slow 
A
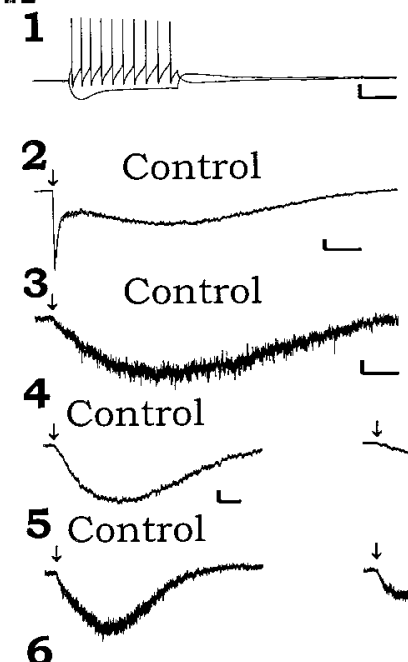

6

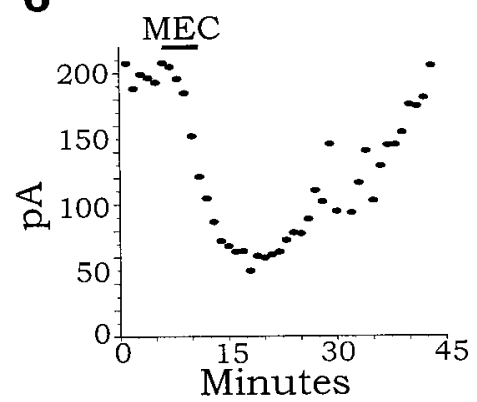

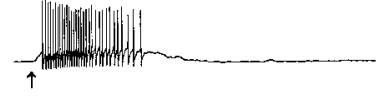
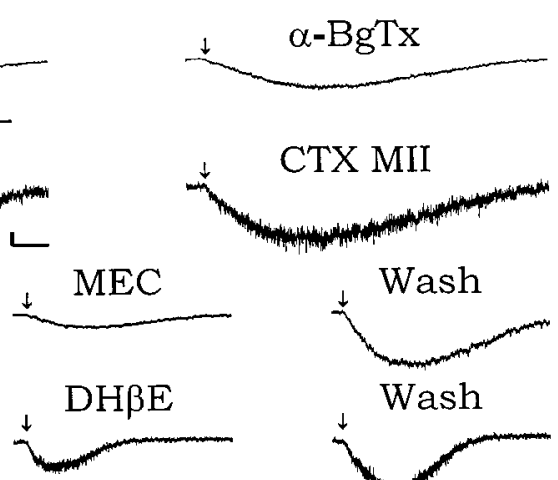

B
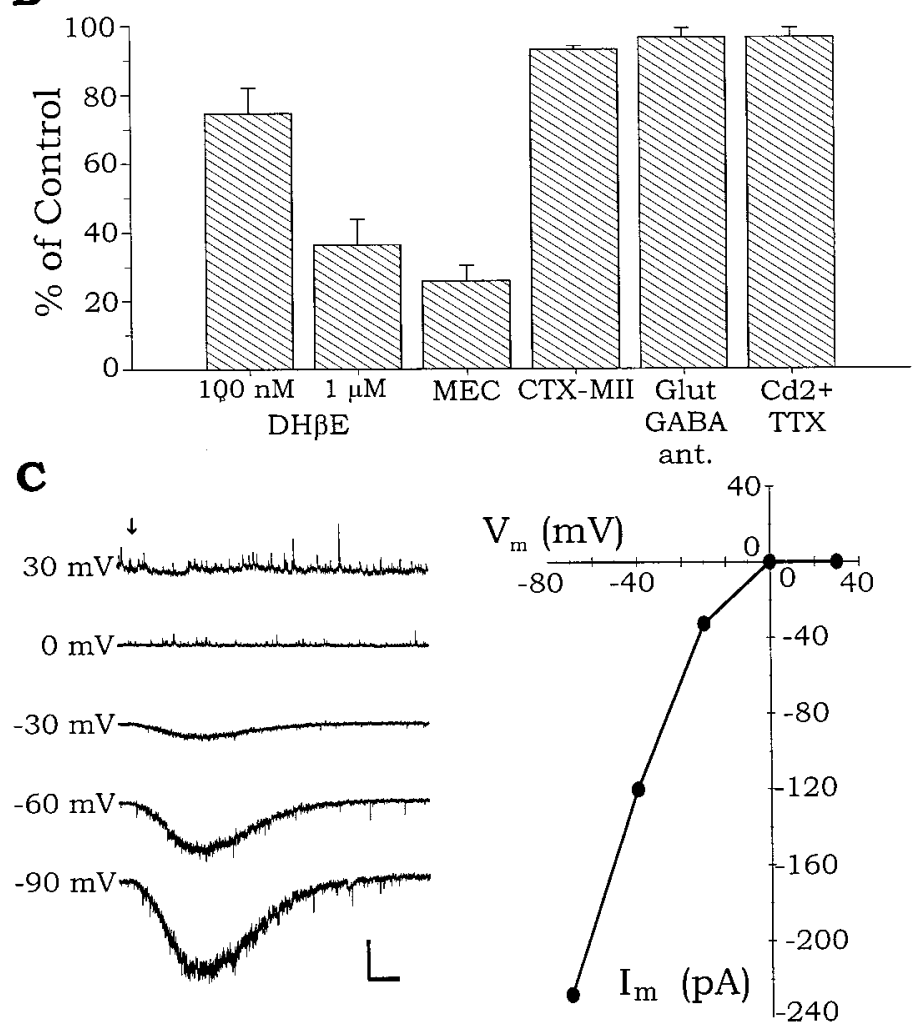

Figure 2. A subset of interneurons in SO are excited by two kinetically distinct nicotinic responses. $A_{1}$, Left, Cell membrane responses to hyperpolarizing and depolarizing current injection $(120 \mathrm{pA})$. Right, Slow membrane depolarization and action potentials of a cell in response to brief pressure application of ACh (arrow) onto the soma. The cell was treated with atropine $(1 \mu \mathrm{M})$ to block muscarinic receptors and $100 \mathrm{nM} \alpha$-BgTx to block the fast $\alpha 7$ nAChRs. $A_{2}$, Left, In another SO interneuron, pressure application of ACh to the cell soma induced a fast and a slow inward current response voltage-clamped at $-70 \mathrm{mV}$. The $\alpha 7$ antagonist a-BgTx $(100 \mathrm{nM})$ completely blocked the fast inward current but did not affect the slow inward current. $A_{3}$, The $\alpha 3 \beta 2 \mathrm{nAChR}$ antagonist $\alpha$-CTX MII (200 nM) did not affect the slow nicotinic current in another SO interneuron. $A_{4}$, The nonselective nicotinic antagonist MEC $(1 \mu \mathrm{M})$ reversibly inhibited the slow nicotinic current in another SO interneuron. $A_{5}$, The nonselective nicotinic antagonist $\mathrm{DH} \beta \mathrm{E}$ inhibited the slow nicotinic current in another SO interneuron. $A_{6}$, Left, A plot of the peak inward current of a slow nicotinic response and its inhibition by MEC over time. Data from the same cell in $A_{4}$. Right, A plot of the peak inward current of the slow nicotinic response and its concentration-dependent inhibition by $\mathrm{DH} \beta \mathrm{E}$ from the cell in $A_{5} . B$, Summary plot of the effects of different antagonists on the slow nicotinic current expressed as a percentage of control amplitude. $C$, Left, Raw data traces of the slow nicotinic current response held at varying membrane potentials. Right, The peak amplitudes of the nicotinic currents plotted against the membrane potentials at which they were recorded. Calibration: $A_{1}$, Vertical, $20 \mathrm{mV}$, horizontal, left, $200 \mathrm{msec}$, right, $1 \mathrm{sec} ; A_{2}$, vertical, $100 \mathrm{pA}$, horizontal, $1 \mathrm{sec} ; A_{3}$, vertical, $20 \mathrm{pA}$, horizontal, $1 \mathrm{sec} ; A_{4,5}$, vertical, $20 \mathrm{pA}$, horizontal, $1 \mathrm{sec} ; C$, vertical, $100 \mathrm{pA}$, horizontal, $1 \mathrm{sec}$.

nicotinic response. Therefore, it is likely that $\mathrm{ACh}$ acts directly on nAChRs on the cell bodies of the interneurons.

Under the same conditions used to measure the fast nicotinic current, the measurement of the slow $I-V$ relationship showed a strong inward rectification (Fig. $2 C$ ). Little or no current was observed between 0 and $+10 \mathrm{mV}(+4.4 \pm 5.5 \mathrm{pA} ; n=9)$. These observations are consistent with the currents being the result of the activation of a neuronal nicotinic current. A few interneurons having a slow response were also found in the stratum lacunosum/ moleculare (4 of 20 interneurons). These responses were considerably smaller than those recorded in interneurons of the SO. In the overall population of interneurons, $\sim 50 \%$ showed only the fast response, whereas $\sim 36 \%$ showed both the fast and slow response, although most of these were found in the SO. The percentage of interneurons with both fast and slow responses is somewhat over-represented in the SO because late in the study we found we were able to identify them before recording, on the basis of their morphological characteristics. The breakdown of response type by hippocampal layer is shown in Table 1.

\section{Some interneurons and most pyramidal cells do not have nicotinic responses}

Although virtually all interneurons located in the neuropil layers showed a nicotinic response, many interneurons located primarily in or near the pyramidal cell layer did not respond at all to brief applications of ACh. (Fig. 3, Table 1). An example of such an interneuron is illustrated in Figure 3 . This cell displayed nonaccommodating rapidly firing action potentials in response to depolarizing current injection and a small depolarizing sag to hyperpolarizing current injection that overshot the resting membrane potential after termination of the current pulse (Fig. $3 A$ ). However, ACh-nonresponsive interneurons showed a variety of firing behaviors. Some showed slower firing rates and significant accommodation to depolarizing current pulses. In this cell, ACh did not cause a membrane depolarization in current clamp (Fig. $3 B)$ or an inward current in voltage clamp $\left(V_{\mathrm{H}}=-70 \mathrm{mV}\right.$; Fig. $3 C$ ). However, ACh (Fig. 3C, arrow) did sometimes induce a barrage of spontaneous EPSCs (observed in 3 of 22 nonrespon- 


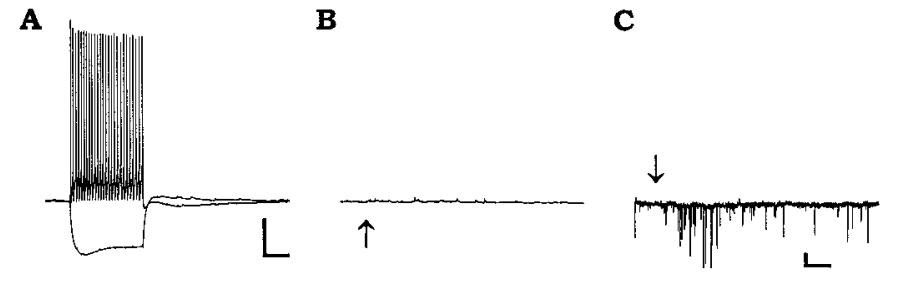

Figure 3. Some interneurons do not respond to nicotinic agonist. All recordings in this figure are from an interneuron with its cell body in the pyramidal cell layer. $A$, Membrane responses to depolarizing and hyperpolarizing current injection (120 pA). $B$, Membrane potential response to pressure application of $3 \mathrm{~mm}$ ACh. $C$, Voltage-clamp recording $\left(V_{\mathrm{H}}=\right.$ $-70 \mathrm{mV}$ ) measuring the current response to $3 \mathrm{~mm}$ ACh. Calibration: $A$, $B$, Vertical, $20 \mathrm{mV}$, horizontal, $200 \mathrm{msec}(A) 500 \mathrm{msec}(B)$; $C$, vertical 20 pA, horizontal $500 \mathrm{msec}$.

sive interneurons). These presumed presynaptic actions were not subsequently investigated, although they were also observed with similar frequency in ACh-responsive interneurons.

Like nonresponsive interneurons, pyramidal cells usually displayed no response to brief applications of ACh (Fig. 4A). Application of ACh to the soma of pyramidal cells usually did not cause a depolarization (Fig. $4 A_{2}$ ) or an inward current under voltage clamp (Fig. $4 A_{3}$ ). However, 2 of 15 pyramidal cells did respond to ACh with small depolarizations and inward currents (10 and $20 \mathrm{pA}$ peak amplitudes; Fig. $4 B_{2,3}$ ) that were much smaller than those typically seen in responsive interneurons. These depolarizations and inward currents were inhibited by MLA (10 nM, Fig. 4 $B_{4}$ ). Pyramidal cells recorded in this study were easily recognized by their familiar electrophysiological properties. They showed spike frequency accommodation to depolarizing current injection, and their action potentials were of longer duration than in interneurons and were followed by small brief afterdepolarizations (Fig. $4 A_{1}, B_{1}$ ). Spike trains were followed by a slow afterhyperpolarizing potential. Hyperpolarizations resulting from current injection showed a depolarizing sag and an overshoot of the resting membrane potential after the termination of the current pulse (Fig. $4 A_{1}, B_{1}$ ).

\section{Low concentrations of nicotine inhibit nicotinic responses in interneurons}

Low concentrations of nicotine, similar to the plasma concentrations reached in smokers after a single cigarette (Benowitz et al., 1989), have been shown to inhibit the activation of different types of nAChR subunits expressed in Xenopus oocytes, presumably because of the desensitization of the receptor (Hsu et al., 1996; Fenster et al., 1997). Figure $5 A$ shows an example of the effect of bath application of low concentrations of nicotine on an interneuron expressing only a fast $\alpha 7$ nicotinic response. A 500 nм concentration of nicotine in the bath reduced the fast nicotinic response in 10 of 14 trials. On average, the fast nicotinic response was inhibited $\sim 31 \%$ ( $69.5 \%$ of control amplitude $\pm 6.1 \%, p=$ 0.04; z-score, $n=14$ ) from a mean control amplitude of $950 \pm 693$ pA by $500 \mathrm{~nm}$ nicotine, a concentration reached in plasma after a cigarette. Higher concentrations of nicotine were more effective, reducing the nicotinic response in all trials. A $1.5 \mu \mathrm{M}$ concentration of nicotine reduced the fast nicotinic current by an average of $\sim 70 \%$ (30.2\% of control amplitude $\pm 7.5 \% ; n=5$ ), and $5 \mu \mathrm{M}$ nicotine reduced it by $\sim 92 \%(7.9 \%$ of control $\pm 3.0 \% ; n=7)$. These effects were reversible (Fig. 5A,B).

Low concentrations of nicotine also desensitized the slow nicotinic response. Slow nicotinic currents were reduced by bath application of $500 \mathrm{~nm}$ nicotine in the bath in 12 of 16 trials. The nicotinic currents (mean amplitude, $97 \pm 34 \mathrm{pA} ; n=16$ ) were reversibly inhibited in a dose-dependent manner $(500 \mathrm{nM}, 1.5 \mu \mathrm{M}$, and $5 \mu \mathrm{M}$ ), as seen in Figure $5 B$. On average, slow nicotinic currents were inhibited $\sim 37 \%$ by $500 \mathrm{~nm}$ nicotine in the bath $(63.4 \%$ of control $\pm 6.2 \% ; p=0.03$; z-score, $n=16), \sim 57 \%$ by 1.5 $\mu \mathrm{M}$ nicotine $(42.7 \pm 5.4 \% ; n=6)$, and by $\sim 87 \%$ in $5 \mu \mathrm{M}$ nicotine $(13.3 \pm 2.5 \% ; n=8 ; p=0.00001, \mathrm{z}$-score, all concentrations, fast and slow) (Fig. 5C).

\section{Distribution and morphology of the different subtypes of interneurons}

Based on nicotinic responsiveness, there appears to be three "response types" of interneurons in area CA1 of the hippocampus. The majority of interneurons have only the fast $\alpha 7$-mediated response. A second response type shows both the fast and the slow non- $\alpha 7$-mediated response. Third, are interneurons that respond not at all to nicotinic agonist. Although at least the first two of these types are found at least to a minor extent in all layers of CA1, they are not uniformly distributed across these layers. Table 1 shows the distribution of interneurons of different response types across the layers of the hippocampus. All interneurons in the stratum radiatum (SR) and stratum lacunosum moleculare (SLM) responded to ACh. Of these interneurons, almost all exhibited only the $\alpha 7$-mediated fast responses (37 of 41). A few of these interneurons (4 of 41) also showed a very small slow non- $\alpha 7$ nicotinic response in addition to the fast response. These were all found within the SLM. The slow responses that were recorded in SLM were considerably smaller in amplitude than those recorded in the SO (an average of $18 \pm 19 \mathrm{pA}, n=4$ in SLM, compared with $97 \pm 34 \mathrm{pA}, n=16$ in a representative sample of SO interneurons; $V_{\mathrm{H}}=-70 \mathrm{mV}$ ). When recording membrane potential, the slow response in SLM interneurons averaged $<2 \mathrm{mV}$.

The SO contained interneurons that fell into all three categories of nicotinic responses. However, unlike the SR and SLM, a large proportion of interneurons recorded here expressed both the fast $\alpha 7$ nicotinic response and the slow non- $\alpha 7$ nicotinic response (63\% of cells recorded showed both responses). In our recordings, the large majority of interneurons having slow responses are found in SO $(>90 \%)$. However, as mentioned before, the proportion of slow-responding cells within SO is somewhat overestimated, because late in this study it became possible to identify these interneurons by their characteristic morphology. This ability to select for slow responding cells makes it impossible to give an accurate numerical indication of the proportion of the whole SO population having both fast and slow responses. However, what is clear is that these slow nicotinic responses are almost absent from other CA1 layers, and in the SO, are confined primarily to neurons having spindle-shaped dendritic fields and somata that are horizontally oriented relative to the alveus (Fig. $6 B$ ). Besides interneurons having a slow response, there were also many that had only the fast response $(32 \%)$, and some did not respond to $\mathrm{ACh}$ at all (5\%), although these nonresponders were always found near the border with SP.

Stratum pyramidale (SP) also contained interneurons of all response types, including nicotinic-insensitive neurons. The fast $\alpha 7$ nicotinic response was observed in $44 \%$ of the interneurons of the SP. However, nicotinic responses in interneurons in SP were typically smaller than those seen in other layers (peak current amplitude, $299.3 \pm 101.0 \mathrm{pA} ; n=14$ for fast responses in SP vs $730.2 \pm 80.4 \mathrm{pA} ; n=80$ for fast responses in other layers; $p=$ 


\begin{tabular}{llcr}
\hline \multicolumn{1}{l}{ Table 1. Distribution of nicotinic receptor actions among the different layers in the CA1 region of the hippocampus } \\
& Fast response $(\%)$ & Fast and slow response $(\%)$ & No response $(\%)$ \\
\hline Stratum oriens & $26(32)$ & $52(63)$ & $4(5)$ \\
Stratum pyramidale & $16(44)$ & $2(6)$ & $18(50)$ \\
Pyramidal cell & $2(13)^{*}$ & $0(0)$ & $13(87)$ \\
Stratum radiatum & $21(100)$ & $0(0)$ & $0(0)$ \\
Stratum lacunosum-moleculare & $16(80)$ & $4(20)^{* *}$ & $0(0)$ \\
\end{tabular}

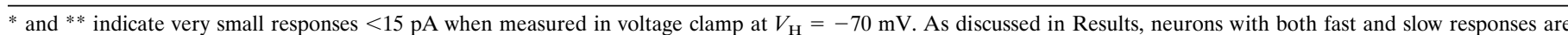
somewhat over-represented because these cells could be visually identified and selected later in the study.

0.0021 , unpaired $t$ test). These smaller responses were often insufficient to evoke action potentials. Only $6 \%$ of the interneurons in SP showed both fast and slow nicotinic responses, many fewer than in SO. The interneuron population differed greatly from the other layers in that $50 \%$ of interneurons in SP showed no response to $\mathrm{ACh}$ at all. Eighty-two percent of nonresponsive interneurons were localized to the SP layer or its boundary. The remaining nicotinic-unresponsive interneurons were located in SO.

Although some interneurons with similar anatomical morphologies and roles in the hippocampus are concentrated in one layer of CA1, other morphological types are found in several layers of CA1 (Freund and Buzsaki, 1996). Therefore, the location of the cell body of the interneuron does not necessarily reflect the role of that interneuron in the hippocampus. To examine directly whether nicotinic response types could be correlated with certain morphological characteristics, we filled a distributed sample of interneurons (and also pyramidal cells) with neurobiotin for later anatomical identification. Seventeen interneurons and three pyramidal cells were examined in this way. Both their axons and dendrites could largely be reconstructed and localized.

An interneuron typical of those that exclusively displayed a fast $\alpha 7$ nicotinic response is shown in Figure $6 A$. This interneuron had its cell body located at the border of SR and SLM, its dendrites were confined to SR and SLM, and its axon projected to SLM exclusively. Four other reconstructed interneurons from SR and SLM, which only exhibited $\alpha 7$ responses, showed varying morphology, but their axons always ramified in hippocampal layers containing the pyramidal cell dendrites (SLM, SR, and/or
SO) while avoiding the pyramidal cell body layer. Similarly, an SO interneuron responding with only an $\alpha 7$ response also had an axonal projection to $\mathrm{SO}$ and SR, avoiding the cell body layer except to pass through to the SR.

A representative tracing of an $\mathrm{SO}$ interneuron that showed both the fast and the slow nicotinic response is shown in Figure $6 B$. This type of interneuron, previously identified and termed an oriens lacunosum moleculare, or OLM cell (Freund and Buzsaki, 1996), had its cell body localized to the SO and horizontally oriented dendrites confined to the SO. Its axon showed a small amount of local ramification, but most of the axon projected to the SLM where it profusely ramified within that layer. Similar morphology was seen in the other four reconstructed cells displaying both slow and fast nicotinic responses.

Figure $6 C$ shows an interneuron typical of those with no response to ACh. Its cell body was found in at the border of the SP and SO, and its dendrites were found in all layers, whereas its axon was confined primarily to the pyramidal cell body layer. Four other nonresponding interneurons showed similar morphology. Two other nonresponding cells, one with its cell body in SO and one at the border of SR and SP, both had axons projecting selectively to the pyramidal cell body layer. Therefore, it would appear that interneurons that do not express functional somatic nAChRs exert their inhibition at the cell bodies of neurons within the pyramidal layer, whereas nicotine responsive interneurons exert their influence outside this layer. This appears to be a strong principal of CA1 interneuronal organization, but not completely absolute, because we did identify one interneuron with its soma in

Figure 4. Most pyramidal cells do not respond to nicotinic agonist, but some show a small response. $A$, A recording from a pyramidal cell that was unresponsive to nicotinic agonist, representing the majority of pyramidal cells recording. $A_{1}$, Membrane potential responses to depolarizing and hyperpolarizing current injections ( $300 \mathrm{pA}) . A_{2}$, The lack of effect of pressure application of $3 \mathrm{~mm}$ ACh (applied at the mark) on the membrane potential or the membrane current $\left(A_{3}\right.$; voltage clamp, $V_{\mathrm{H}}=$ $-70 \mathrm{mV}$ ) of the pyramidal cell. $B$, Recordings from a pyramidal cell showing a small response to nicotinic agonist, representing the minority of pyramidal cells. $B_{1}$, Membrane response to depolarizing and hyperpolarizing current injection. $B_{2}$, Response of membrane potential to pressure application of $3 \mathrm{~mm}$ $\mathrm{ACh}$ to the soma. $B_{3}$, Response in membrane current to identical application of

$\mathbf{A}$

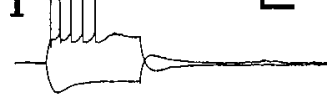

B

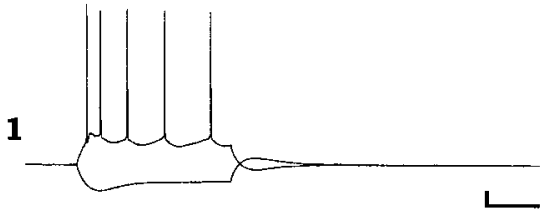

3

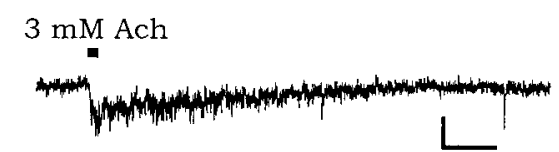

3

$3 \mathrm{mM}$ Ach
2

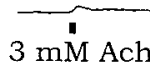

$4 \quad 10 \mathrm{nM}$ MLA

$3 \mathrm{mM} \mathrm{Ach}$

ACh. $B_{4}$, This response was blocked by $10 \mathrm{~nm}$ MLA. Calibration: $A, 10 \mathrm{mV}, 100 \mathrm{pA}, 200 \mathrm{msec}, 500 \mathrm{msec} ; B_{1,2}, 10 \mathrm{mV}, 200 \mathrm{msec}, 500 \mathrm{msec} ; B_{3,4}, 20 \mathrm{pA}$, $500 \mathrm{msec}$. 


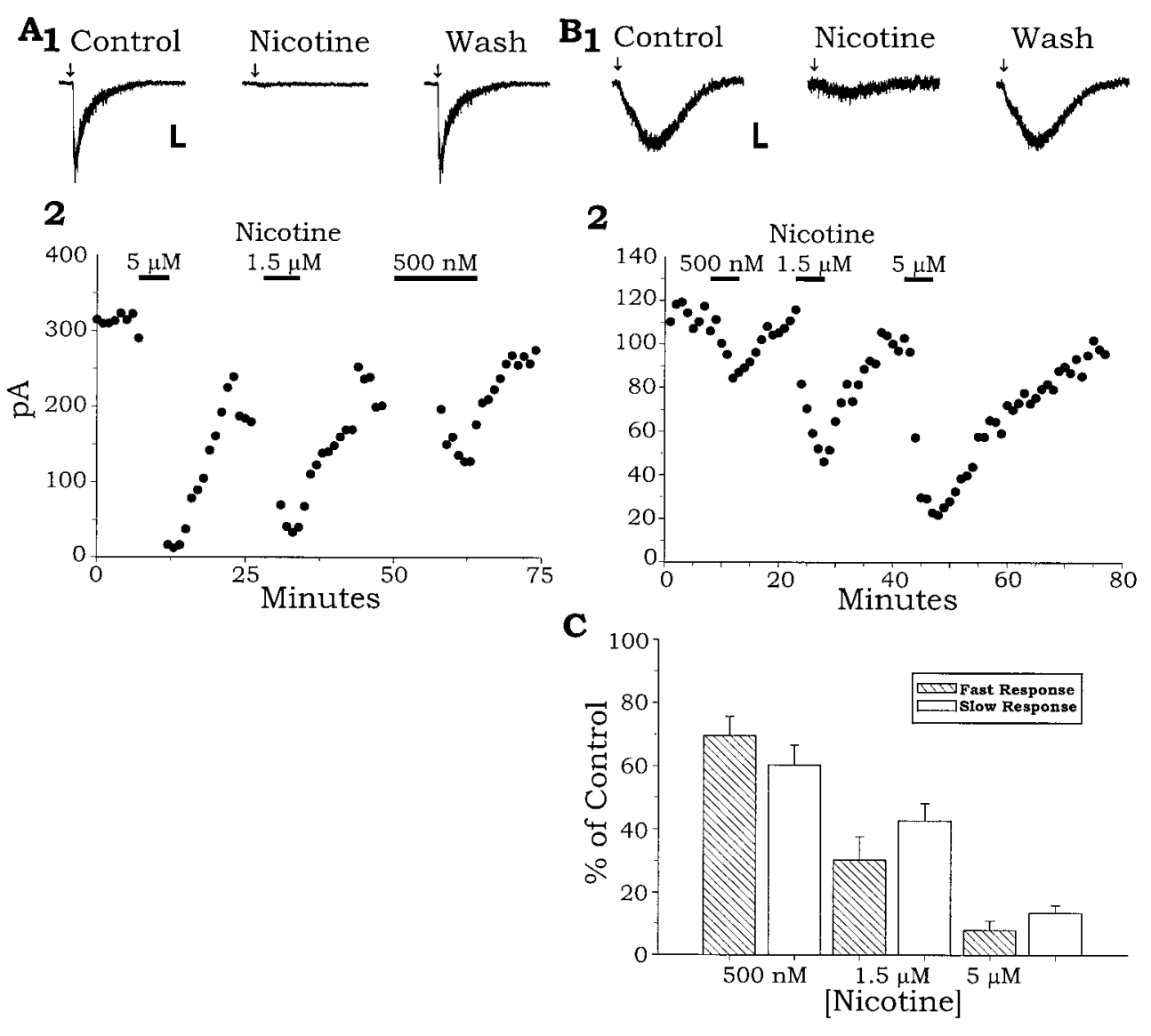

Figure 5. Low concentrations of nicotine inhibit both the fast $\alpha 7$ nicotinic and the slow non- $\alpha 7$ nicotinic response. $A_{1}$, Reversible inhibition of the fast nicotinic current by bath-applied nicotine $(5 \mu \mathrm{M})$. $A_{2}$, A plot of the peak fast inward currents (same cell as $A_{1}$ ) throughout the entire experiment showing the reversible inhibition by the varying concentrations of nicotine on the nicotinic currents. $B_{1}$, Reversible inhibition of the slow nicotinic currents by bath-applied nicotine $(5 \mu \mathrm{M})$. $B_{2}$, A plot of the peak slow inward currents (same cell as $B_{1}$ ) throughout the experiment show the reversible inhibition of the slow nicotinic currents by concentrations of nicotine. $C$, Summary showing that $500 \mathrm{~nm}$ to $5 \mu \mathrm{M}$ nicotine significantly inhibits both the slow and fast nicotinic current responses across all tested cells. Calibration: $A$, Vertical, 50 $\mathrm{pA}$, horizontal, $500 \mathrm{msec}$; , vertical, 40 pA, horizontal, $1 \mathrm{sec}$.
SO that both responded to ACh and had axon projecting to the pyramidal cell body layer.

Finally, a pyramidal cell that did not produce a nicotinic response is shown in Figure $6 D$. One other reconstructed pyramidal cell that did respond to ACh and one that did not respond to ACh showed similar morphology.

\section{DISCUSSION}

Interneurons in hippocampal area CA1 fall into three classes with regard to their nicotinic response to rapid ACh application: (1) interneurons with a nicotinic fast inward current mediated by $\alpha 7$ nAChR activation, (2) interneurons with a fast response and an additional slow non- $\alpha 7$-mediated inward current, and (3) interneurons that do not respond. This classification correlates strongly with morphological characteristics of interneurons. Interneurons with only a fast response project their axonal arbors to neuropil layers in area CA1. An individual interneuron of this type may have its arbors confined to a particular layer, but as a group, they project to all layers, except for being almost entirely excluded from the pyramidal cell layer. Most of the interneurons having an additional slow response, OLM cells as described by Freund and Buzsaki (1996), are found in SO, although a few having a much smaller slow nicotinic response were also found in SLM. Unresponsive interneurons are found almost exclusively in or on the border of SP and appear to be basket cells or axo-axonic cells.

The fast nicotinic response is clearly mediated by an $\alpha 7$ nicotinic receptor. It is completely blocked by low concentrations of $\alpha$-bungarotoxin and MLA. It shows the inward rectification characteristic of $\alpha 7$ responses, although we find this rectification to be more variable than sometimes previously reported, ranging from mild as seen in Figure 1, to nearly complete. However, the amount of rectification observed is not outside the normal range seen for these receptors, particularly for the internal magnesium concentration used (cf. Albuquerque et al., 1996). The slow response, on the other hand, is mediated by a nicotinic receptor of an unidentified type. It is not blocked by the $\alpha$-bungarotoxin or MLA, but is reduced by MEC and high concentrations of $\mathrm{DH} \beta \mathrm{E}$. This response was always seen in combination with the fast response, never alone.

Three different types of functional nAChRs in interneurons have been described (Alkondon and Albuquerque, 1993). They found that $>90 \%$ of nicotinic responses were caused by the activation of $\alpha 7$ receptors (type 1a). Two other slower responses were described, one inhibited by low concentrations of $\mathrm{DH} \beta \mathrm{E}(10$ $\mathrm{nM})$ (type II) and another inhibited by MEC (1 $\mu \mathrm{M})$ (type III) (Alkondon and Albuquerque, 1993). Cells with type II responses expressed $\alpha 4$ nAChR mRNA (Albuquerque et al., 1995). Although the hippocampus contains small amounts of mRNA for $\alpha 2-4$ (Wada et al., 1989), it is unlikely that the slow nicotinic response we observed is the result of the activation of the $\alpha 4$ containing receptor observed by Albuquerque et al. (1995), because the slow response we observed was not sensitive to low concentrations of $\mathrm{DH} \beta \mathrm{E}$. However, it cannot be ruled out that the slow response we observed includes an $\alpha 4$-containing receptor, because the $\beta$ subunits can dramatically influence nAChR pharmacology. $\mathrm{nAChRs}$ in culture and $\mathrm{nAChRs}$ we observe may contain different compliments of $\beta$ subunits while still containing the $\alpha 4$ subunit. However, the pharmacology and kinetics of our 


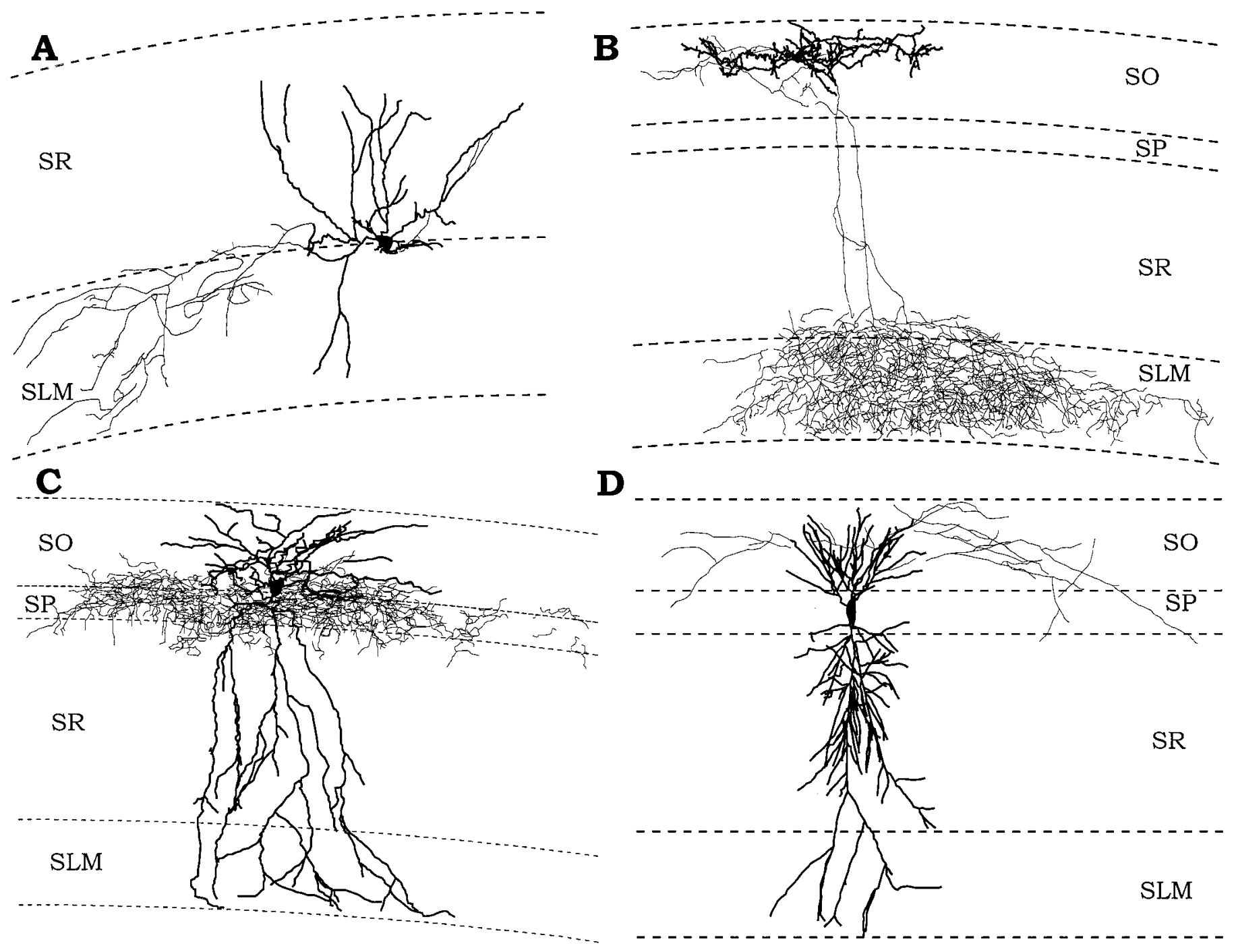

Figure 6. Morphology of different subsets of interneurons that express different compliments of nAChRs. The lighter line in each tracing is the axon, and the darker line is the dendrite of each illustrated neuron. $A$, An example of an interneuron with its soma located at the SR/SLM border that responded to nicotinic agonist with only a fast $\alpha 7$ nicotinic response. Its dendrite ramified mostly within SR, but also in SLM. Its axon was contained almost entirely within SLM with a small projection to SR. B, An example of an OLM-type interneuron that responded with both the fast $\alpha 7$ and slow non- $\alpha 7$ nicotinic response. Its dendrite was located entirely within SO and was oriented parallel to the alveus. Its axon had a small projection to SO, but ramified widely in SLM. C, An example of an interneuron that did not respond to nicotinic agonist. Its dendritic tree was found across all layers of CA1, but its axon was confined to an area in and bordering SP. D, A pyramidal cell that does not respond to nicotinic agonist. We detected no difference in the morphologies of pyramidal cell that did not respond to agonist and those that responded with a small response.

slow response is more consistent with the MEC-sensitive type III nicotinic response observed in culture (Alkondon and Albuquerque, 1993). The slow nicotinic response is not likely caused by the activation of an $\alpha 3 \beta 2$-containing $\mathrm{nAChR}$, because it was not inhibited by $\alpha$-CTX MII (Cartier et al., 1996). Another candidate for the slow nicotinic response may be an nAChR that includes the $\alpha 2$ subunit (Luetje and Patrick, 1991).

We also made several recordings from pyramidal neurons and tested their responsiveness to nicotine. Reports from studies in cultured neurons (Alkondon et al., 1996) reported that both "pyramidal-type" cells and presumed interneurons in primary culture were sensitive to nicotine. Pyramidal cells in hippocampal slices were also reported respond to nicotine with a slow response (Alkondon et al., 1997). However, Frazier et al. (1998a) found pyramidal cells to be completely unresponsive to nicotinic recep- tor activation. Our results agree to the largest extent with Frazier et al. (1998a). Although we did find pyramidal cells that responded to nicotine with a fast $\alpha 7$-mediated inward current, this was rare, and when they did appear, the responses were very small, averaging $\sim 1 / 30$ th the size of those seen on average in interneurons. We never recorded a slow nicotinic response in pyramidal cells. The earlier reports of nicotinic responsiveness of cells in primary culture could have arisen from two sources. First, pyramidal type neurons may not actually be pyramidal neurons, but rather interneurons with pyramidal shape. Second, it is possible that pyramidal cells in culture may express a different compliment of nicotinic receptors than mature neurons in brain. The conclusion we reach from our own data are that pyramidal cells are largely nonresponsive to nicotine, although perhaps not entirely in all cases. 


\section{Potential functional consequences of nonuniform nicotinic responsiveness in interneurons}

Interneurons falling into different morphological categories have varying targets of their axonal arbors and thus, presumably have different roles in the hippocampus (Freund and Buzsaki, 1996). Functionally, these morphological subclasses of interneurons are believed to include those that inhibit pyramidal cell dendrites or somata (Harris et al., 1985; Nunzi et al., 1985; Kawaguchi and Hama, 1988; Gulyas et al., 1991, 1993a; Buhl et al., 1994; Sik et al., 1995; Acsady et al., 1996a,b) to project out of CA1 (Sik et al., 1994, 1995) or to innervate other interneurons (Acsady et al., 1996a,b; Gulyas and Freund, 1996; Hajos et al., 1996).

Although nicotinic fast-only responders comprise a diverse group of morphological types, it is clear that virtually all of these interneurons share the characteristic of having their axonal projections in the neuropil layers of CA1 and excluded from the pyramidal cell layer. These interneurons may mediate feedforward inhibition (Lacaille and Schwartzkroin, 1988) because they are in a position to receive input from fibers entering the CA1 and to inhibit the dendritic areas of pyramidal cells. In addition to being activated by glutamatergic inputs, these interneurons may be excited by cholinergic inputs acting on their $\alpha 7$ receptors. It has been reported that at least some hippocampal interneurons (in $\mathrm{SR}$ ) receive functional cholinergic inputs that generate $\alpha 7$-mediated synaptic responses (Frazier et al., 1998b). These synaptic responses are incompletely inhibited by concentrations of the $\alpha 7$ antagonist MLA (50-75 nM), higher than needed to give complete block of exogenous ACh responses (1-10 $\mathrm{nM})$. Despite considerable effort, we were unable to detect any fast excitatory synaptic potentials that were not blocked by elevated concentrations of the glutamate receptor antagonist NBQX (40-50 $\mu \mathrm{M}$; data not shown).

Interneurons that show both fast and slow nicotinic responses appear to be mostly the OLM cells described by Freund and Buzsaki (1996). These cells may monitor activity of CA1 pyramidal cells and in turn, potently inhibit excitatory input coming into the hippocampus from the perforant path or other dendritic inputs (Gulyas et al., 1993a,b; McBain et al., 1994; Sik et al., 1995; Yanovsky et al., 1997). In this sense, these are more in the character of classical feedback inhibitory interneurons, except that they may be inhibiting the inputs to pyramidal cells (Yanovsky et al., 1997), rather than directly exerting this inhibition on the somata. Because these cells have $\alpha 7$ nicotinic responses, they could be directly excited by cholinergic input in the classical sense of nicotinic synapses. If a slower nicotinic response is also synaptically evoked, then these interneurons might also exhibit a prolonged activity after this activation. Such non- $\alpha 7-$ mediated nicotinic prolonged synaptic potentials $(\mathrm{DH} \beta \mathrm{E}-$ sensitive) have been recorded in ferret visual cortex (Roerig et al., 1997).

The axonal arborization patterns of nicotine-responsive interneurons suggest that as a group, these interneurons exert their synaptic inhibition primarily on the dendrites of CA1 pyramidal neurons or on the inputs to those dendrites. Nonresponsive interneurons, on the other hand, appear to be mostly basket type or axo-axonic interneurons having both axons and dendrites that ramify almost exclusively around the pyramidal cell layer. As such, they must exert their inhibition mostly on the pyramidal cell somata. From this, one could hypothesize that as a group, nicotine-responsive interneurons may be involved primarily with influencing the input to area CA1, whereas unresponsive inter- neurons may have their influence primarily on the output. Thus, the influence of cholinergic inputs from outside the hippocampus would, at least in CA1, be to suppress input activity by stimulating interneurons that suppress this input.

This hypothesis is particularly interesting when considered in light of the data from this study and others (Frazier et al., 1998a) on the effects on tonic nicotine application on nicotinic responses in interneurons. The blockade of ACh responses by bath-applied nicotine suggests that the action of self-administered nicotine is not to activate the nicotinic receptors of the brain, but rather to functionally inhibit them. Second, they suggest that ingestion of nicotine would hamper the ability of cholinergic nuclei outside the hippocampus to influence the inhibition in area CA1, without a direct effect on the output from CA1 pyramidal cells. In the particular case of OLM cells, self-administered nicotine might hamper the ability of pyramidal cell output to feedback-regulate the inputs to the distal dendrites of the same or other pyramidal cells.

\section{REFERENCES}

Acsady L, Arabadzisz D, Freund TF (1996a) Correlated morphological and neurochemical features identify different subsets of vasoactive intestinal polypeptide-immunoreactive interneurons in rat hippocampus. Neuroscience 73:299-315.

Acsady L, Gorcs TJ, Freund TF (1996b) Different populations of vasoactive intestinal polypeptide-immunoreactive interneurons are specialized to control pyramidal cells or interneurons in the hippocampus. Neuroscience 73:317-334.

Albuquerque EX, Pereira EF, Castro NG, Alkondon M, Reinhardt S, Schroder H, Maelicke A (1995) Nicotinic receptor function in the mammalian central nervous system. Ann NY Acad Sci 757:48-72.

Albuquerque EX, Pereira EFR, Bonfante-Cabarcas R, Marchioro M, Matsubayashi H, Alkondon M, Maelicke A (1996) Nicotinic acetylcholine receptors on hippocampal neurons: cell compartment-specific expression and modulatory control of channel activity. Prog Brain Res 109:111-124.

Alkondon M, Albuquerque EX (1991) Initial characterization of the nicotinic acetylcholine receptors in rat hippocampal neurons. J Recept Res 11:1001-1021.

Alkondon M, Albuquerque EX (1993) Diversity of nicotinic acetylcholine receptors in rat hippocampal neurons. I. Pharmacological and functional evidence for distinct structural subtypes. J Pharmacol Exp Ther 265:1455-1473.

Alkondon M, Pereira EFR, Albuquerque EX (1996) Mapping the location of functional nicotinic and $\gamma$-aminobutyric $\operatorname{acid}_{\mathrm{A}}$ receptors on hippocampal Neurons. J Pharmacol Exp Ther 279:1491-1506.

Alkondon M, Pereira EFR, Barbosa CTF, Albuquerque EX (1997) Neuronal nicotinic acetylcholine receptor activation modulates $\gamma$-aminobutyric acid release from CA1 neurons of rat hippocampal slices. J Pharmacol Exp Ther 283:1396-1411.

Benowitz NL, Porchet H, Jacob P (1989) Nicotine dependence and tolerance in man: pharmacokinetic and pharmacodynamic investigations. Prog Brain Res 79:279-287.

Bolam JP (1992) Experimental neuroanatomy: a practical approach. Oxford: Oxford UP.

Buhl EH, Halasy K, Somogyi P (1994) Diverse sources of hippocampal unitary inhibitory postsynaptic potentials and the number of synaptic release sites. Nature 368:823-828.

Cartier GE, Yoshikami D, Gray WR, Luo S, Olivera BM, McIntosh JM (1996) A new $\alpha$-conotoxin which targets $\alpha 3 \beta 2$ nicotinic acetylcholine receptors. J Biol Chem 271:7522-7528.

Dodt HU, Zieglgansberger W (1990) Visualizing unstained neurons in living brain slices by infrared DIC-videomicroscopy. Brain Res 537:333-336.

Fenster CP, Rains MF, Noerager B, Quick MW, Lester RA (1997) Influence of subunit composition on desensitization of neuronal acetylcholine receptors at low concentrations of nicotine. J Neurosci 17:5747-5759.

Frazier CJ, Rollins YD, Breese CR, Leonard S, Freedman R, Dunwiddie TV (1998a) Acetylcholine activates an $\alpha$-bungarotoxin-sensitive nico- 
tinic current in rat hippocampal interneurons, but not pyramidal cells. J Neurosci 18:1187-1195.

Frazier CJ, Buhler AV, Weiner JL, Dunwiddie TV (1998b) Synaptic potentials mediated via $\alpha$-bungarotoxin-sensitive nicotinic acetylcholine receptors in rat hippocampal interneurons. $\mathrm{J}$ Neurosci 18:8228-8235.

Freedman R, Wetmore C, Stromberg I, Leonard S, Olson L (1993) $\alpha$-Bungarotoxin binding to hippocampal interneurons: immunocytochemical characterization and effects on growth factor expression. J Neurosci 13:1965-1975.

Freund TF, Buzsaki G (1996) Interneurons of the hippocampus. Hippocampus 6:347-470.

Frotscher M, Nitsch R, Leranth C (1989) Cholinergic innervation of identified neurons in the hippocampus: electron microscopic double labeling studies. In: The hippocampus: new vistas (Chan-Palay V, Kohler C, eds), pp 85-96. New York: Alan R. Liss.

Gray R, Rajan AS, Radcliffe KA, Yakehiro M, Dani JA (1996) Hippocampal synaptic transmission enhanced by low concentrations of nicotine. Nature 383:713-716.

Gulyas AI, Freund TF (1996) Pyramidal cell dendrites are the primary targets of calbindin D28k-immunoreactive interneurons in the hippocampus. Hippocampus 6:525-534.

Gulyas AI, Toth K, Danos P, Freund TF (1991) Subpopulations of GABAergic neurons containing parvalbumin, calbindin D28k, and cholecystokinin in the rat hippocampus. J Comp Neurol 312:371-378.

Gulyas AI, Miles R, Hajos N, Freund TF (1993a) Precision and variability in postsynaptic target selection of inhibitory cells in the hippocampal CA3 region. Eur J Neurosci 5:1729-1751.

Gulyas AI, Miles R, Sik A, Toth K, Tamamaki N, Freund TF (1993b) Hippocampal pyramidal cells excite inhibitory neurons through a single release site. Nature 366:683-687.

Hajos N, Acsady L, Freund TF (1996) Target selectivity and neurochemical characteristics of VIP-immunoreactive interneurons in the rat dentate gyrus. Eur J Neurosci 8:1415-1431.

Han ZS, Buhl EH, Lorinczi Z, Somogyi P (1993) A high degree of spatial selectivity in the axonal and dendritic domains of physiologically identified local-circuit neurons in the dentate gyrus of the rat hippocampus. Eur J Neurosci 5:395-410.

Harris KM, Marshall PE, Landis DM (1985) Ultrastructural study of cholecystokinin-immunoreactive cells and processes in area CA1 of the rat hippocampus. J Comp Neurol 233:147-158.

Hsu YN, Amin J, Weiss DS, Wecker L (1996) Sustained nicotine exposure differentially affects $\alpha 3 \beta 2$ and $\alpha 4 \beta 2$ neuronal nicotinic receptors expressed in Xenopus oocytes. J Neurochem 66:667-675.

Hunt SP, Schmidt J (1978) The electron microscopic autoradiographic localization of $\alpha$-bungarotoxin binding sites within the central nervous system of the rat. Brain Res 142:152-159.

Johnson DS, Martinez J, Elgoyhen AB, Heinemann SF, McIntosh JM (1995) $\alpha$-Conotoxin ImI exhibits subtype-specific nicotinic acetylcholine receptor blockade: preferential inhibition of homomeric $\alpha 7$ and $\alpha 9$ receptors. Mol Pharmacol 48:194-199.

Jones S, Yakel JL (1997) Functional nicotinic ACh receptors on interneurones in the rat hippocampus. J Physiol (Lond) 504:603-610.

Kawaguchi Y, Hama K (1988) Physiological heterogeneity of nonpyramidal cells in rat hippocampal CA1 region. Exp Brain Res 72:494-502.

Lacaille JC, Schwartzkroin PA (1988) Stratum lacunosum-moleculare interneurons of hippocampal CA1 region. II. Intrasomatic and intradendritic recordings of local circuit synaptic interactions. J Neurosci 8:1411-1424.

Luetje CW, Patrick J (1991) Both $\alpha$ - and $\beta$-subunits contribute to the agonist sensitivity of neuronal nicotinic acetylcholine receptors. J Neurosci 11:837-845.

MacVicar BA (1984) Infrared video microscopy to visualize neurons in the in vitro brain slice preparation. J Neurosci Methods 12:133-139.

McBain CJ, DiChiara TJ, Kauer JA (1994) Activation of metabotropic glutamate receptors differentially affects two classes of hippocampal interneurons and potentiates excitatory synaptic transmission. J Neurosci 14:4433-4445.

McIntosh JM, Yoshikami D, Mahe E, Nielsen DB, Rivier JE, Gray WR, Olivera BM (1994) A nicotinic acetylcholine receptor ligand of unique specificity, $\alpha$-conotoxin ImI. J Biol Chem 269:16733-16739.

Miles R, Toth K, Gulyas AI, Hajos N, Freund TF (1996) Differences between somatic and dendritic inhibition in the hippocampus. Neuron 16:815-823.

Neher E (1992) Correction for liquid junction potentials in patch clamp experiments. Methods Enzymol 207:123-131.

Nunzi MG, Gorio A, Milan F, Freund TF, Somogyi P, Smith AD (1985) Cholecystokinin-immunoreactive cells form symmetrical synaptic contacts with pyramidal and nonpyramidal neurons in the hippocampus. J Comp Neurol 237:485-505.

Pereira EF, Alkondon M, McIntosh JM, Albuquerque EX (1996) $\alpha$-Conotoxin-ImI: a competitive antagonist at $\alpha$-bungarotoxin-sensitive neuronal nicotinic receptors in hippocampal neurons. J Pharmacol Exp Ther 278:1472-1483.

Reece LJ, Schwartzkroin PA (1991) Nicotine exerts differential effects on different CA1 hippocampal cell types. Brain Res 540:287-290.

Roerig B, Nelson DA, Katz LC (1997) Fast synaptic signaling by nicotinic acetylcholine and serotonin 5-HT3 receptors in developing visual cortex. J Neurosci 17:8353-8362.

Role LW (1992) Diversity in primary structure and function of neuronal nicotinic acetylcholine receptor channels. Curr Opin Neurobiol 2:254-262.

Séguéla P, Wadiche J, Dineley-Miller K, Dani JA, Patrick JW (1993) Molecular cloning, functional properties, and distribution of rat brain $\alpha 7$ : a nicotinic cation channel highly permeable to calcium. J Neurosci 13:596-604.

Sik A, Ylinen A, Penttonen M, Buzsaki G (1994) Inhibitory CA1-CA3hilar region feedback in the hippocampus. Science 265:1722-1724.

Sik A, Penttonen M, Ylinen A, Buzsaki G (1995) Hippocampal CA1 interneurons: an in vivo intracellular labeling study. J Neurosci 15:6651-6665.

Wada E, Wada K, Boulter J, Deneris E, Heinemann S, Patrick J, Swanson LW (1989) Distribution of $\alpha 2, \alpha 3, \alpha 4$, and $\beta 2$ neuronal nicotinic receptor subunit mRNAs in the central nervous system: a hybridization histochemical study in the rat. J Comp Neurol 284314-284335.

Wonnacott S (1997) Presynaptic nicotinic ACh receptors. Trends Neurosci 20:92-98.

Yanovsky Y, Sergeeva OA, Freund TF, Haas HL (1997) Activation of interneurons at the stratum oriens/alveus border suppresses excitatory transmission to apical dendrites in the CA1 area of the mouse hippocampus. Neuroscience 77:87-96. 